\title{
PODPORA ROZVOJE MEZIOBECNÍ SPOLUPRÁCE V LR
}

\section{SUPPORT FOR THE DEVELOPMENT OF INTER-MUNICIPAL COOPERATION IN THE CZECH REPUBLIC}

\section{ING. MAREK JETMAR, PH.D.}

\author{
Svaz $m$ ņt a obcí Leské republiky | Unions of Towns and Municipalities of the CR \\ $\triangle$ 5. kv Пna 1640/65, 14021 Praha, Czech Republic \\ E-mail: jetmar.mos@smocr.cz
}

Vysoká ġkola regionálního rozvoje, s.r.o. | College of Regional Development

$\triangle$ G̦alanského 68/54, 16300 Praha, Czech Republic

E-mail: jetmar.marek@seznam.cz

\begin{abstract}
Anotace
Llánek se zabývá problematikou podpory meziobecní spolupráce $v$ Ḷeské republice. PŚináğ informace o prTbhu realizaci projektu Systémová podpora rozvoje meziobecní spolupráce $v L_{T} R v$ rámci území správních obvodT obcí s rozg்Śśnou p丁sobností a o základních zjiğhních z doposud

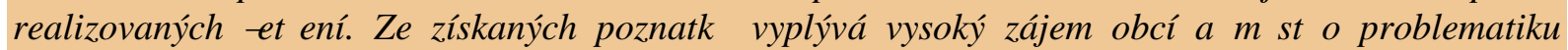
meziobecní spolupráce, vysoký potenciál k jejímu dalğmu rozvoji. Jako pŚiznivé se jeví i yytvoŚení nové formy meziobecní spolupráci v území obcí s rozg்'senou p Tsobností (ORP) ï budoucím Âmalýchñ okresech, která by výraznクposílila postavení obcí.
\end{abstract}

\section{Klị̂lová slova}

obce, $m$ Пta, meziobecní spolupráce

\section{Annotation}

The article deals with the support of inter-municipal cooperation in the Czech Republic. It provides information on the progress of the System project to support the development of inter-municipal cooperation in the Czech Republic within the administrative districts of municipalities with extended powers. The article presents the major findings of the research carried out so far. The findings show a high interest of municipalities and cities in the issue of inter-municipal cooperation, a high potential for further development. As seems to be favorable and the creation of new forms of inter-municipal cooperation in the territory territorial district of municipality with extended power (future ñsmallò district), which would greatly enhance the status of all municipalities (towns and villages).

Key words

municipalities (towns, villages), inter-municipal cooperation

JEL classification: $R 38, R 58$

\section{Úvod}

Leská republika je charakteristická velmi rozdrobenou sídelní strukturou, v mezinárodním srovnání srovnatelnou jen se státy jako jsou napŚ Slovensko !̣i Francie (Hampl, MT̋ller, 1998). K 1. 1. 2013 existuje na území L̦eska dle databáze Ministerstva vnitra 6253 obcí, zatímco napŚklad v Dánsku po reformクveŚjné správy v roce 2007 jen 98 obcí.

Existence velkého pol tu obcí lze na jednu stranu vnímat jako pozitivní, jedná se pŚedevğm o moğnost demokratické participace na správク v'cí veŚjných, zásadní je i pŚblíǵení základní (samo)správy 
obḷ anTm, na druhou stranu vg̉ak s sebou fragmentace obcí pŚnáğ Śidu problémT. Problémem je slabé finan!̣ ní a ekonomické zázemí malých obcí limitujících jejich dalğ rozvoj, zajig̉nní základního standardu sluğeb !̣ i nedostatel ná kvalita veŚjných sluǵeb (Blaǵek, 2002), jejichǵ dostupnost vğak ve svém dTsledku garantuje ob!̣anTm vláda. Hampl a Dostál (2007) podobnクjako negativa uvádí neschopnost nejmenğch obcí provádh velké investillní projekty, zajistit základní sluớby (veŚejná doprava, sbḩ odpadu a jeho svoz/likvidace) a jako problematickou hodnotí také lasto malou kvalifikovanost vedení úśidu.

Je zŚjmé, ǵe Śġením tḩhto výzev není vzhledem k vysokému zastoupení sídel administrativní slu! ování obcí, tak jak se uskutel nilo v Śd円 západoevropských zemí. Zánik samostatného postavení menğch obcí by vedl $\mathrm{k}$ dalğ ztrát门zájmu obḷanT o veŚjné záleğitosti a $\mathrm{k}$ riziku konzervace ne-li zhorǵení dosaǵeného stupnクrozvoje a vybavenosti malých obcí. ř eg̉ením je podpora stávajících forem meziobecní spolupráce (DSO), vị etnクuplatnhí nových forem, které by posílily postavení obcí a mß̧t jako klị́ ového partnera státu a jeho orgánT a organizacím p丁sobících v území, tak i kraj丁 a ekonomických a sociálních partnerT. K problematice moǵnosti uplatnநní meziobecní spolupráce v L R se vyjadŚije Jetmar a Huǵera (2013), k rozvoji nových forem meziobecní spolupráce v!̣ etnn spolupráce v území ORP pak Jetmar (2013a,b).

Jednou z cest, jak zájem o meziobecní spolupráci posílit, vnést téma do veŚjjné debaty, identifikovat a prosadit nové formy meziobecní spolupráce je i realizace projektu ĂSystémová podpora rozvoje meziobecní spolupráce v LLRñ (dále také Projekt), který realizuje Svaz $\mathrm{m}$ \$̧t a obcí L̦R (dále také Svaz).

\section{Zamrsení projektu}

Na podzim roku 2013 se podaŚlo v L̦eské republice zahájit realizaci projektu ĂSystémová podpora rozvoje meziobecní spolupráce $v$ L̦Rñ jehoǵ cílem je vytvoŚt podmínky pro dlouhodobý rozvoj meziobecní spolupráce $\mathrm{v}$ ḶR. Zamrśení projektu vychází jak z domácích zkuǵeností, tak i z analýzy zahranil ních zkuġeností, z nichǵ jednozna! nךvyplývá, ǵe spojení sil umoǵní zkvalitnit a zefektivnit zajiğŠování veŚejné sluğby i získat pro obce a mß̧ta dalğ finan!̣ ní prostŚedky pro jejich rozvoj.

Z dlouhodobého hlediska je cílem projektu docílit podpory státu pro meziobecní spolupráci. Stát by $\mathrm{m} \eta$ výraznク finan! $\mathrm{n} \eta$ podporovat obce, které budou spolupracovat $\mathrm{v}$ území na zajiğhní svých zákonných kompetencí. Projekt umoǵŔuje vytvoŚt pro podporu spolupráce obcí odborné a administrativní zázemí ve vg̉ech územích správních obvodT obcí s rozğŚśnou p丁sobností. Malé týmy pracovníkT, za výrazné podpory motivujících starost $\mathrm{z}$ daného území a metodické podpory ze strany Svazu mḩ̣t a obcí L̦R, umoǵní vytvoŚt ucelené materiály za jednotlivá území, které se stanou impulsem $\mathrm{k}$ dalğmu rozvoji meziobecní spolupráce. Stanou se podkladem pro diskusi zástupc丁 obcí, jak Śğit dostupnost základních g̉kol nebo sociálních sluğeb v území, jaké jsou moǵnosti Śggení

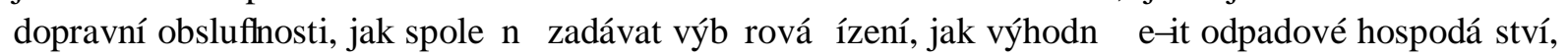
jak spolẹ̣n n nakupovat energie !̣i jiné sluğby apod. Týmy pracovníkT v území se mohou stát zárodkem pro oğivení ! innosti stávajících DSO nebo pro tvorbu nových funk! ních svazkT.

Projekt je ur!̣ en pro vǵechny obce, zvláğ pak pro ty, které nemají dostatek kapacit pro zajiğhní poǵadavkT na nクkladených. Podpora rozhodnクnení omezena pouze na ḷ lenskou základnu Svazu. ProstŚdnictvím prog̉koleného personálu ve 204 vybraných obcích nebo svazcích obcí v území SO ORP jsou vypracovány specifické analýzy a návrhy Śegení rozvoje a koordinace sluǵeb s potenciálem úspor ze spolel né ḷinnosti (napŚ nákup energií, napojení na veŚ́jnou dopravu, svazkové mateŚké ḷi základní ǵkoly, stacionáŚ atd.), které mají pŚnést podnП̧y k rozvoji meziobecní spolupráce. 


\section{Zajiöhní realizace projektu}

Realizace projektu je uskute!̣nha prostŚdnictvím aktivit konkrétních obcí a m\$̧t, které se hlásá k filosofii a cílTm Projektu, podílejí se na jeho aktivitách.

Pro potŚ́by organizování diskusí a jednání o zam伃í meziobecní spolupráce a zpracování podkladových dokument T $\mathrm{k}$ oğivení thạhto debat byl pro kaǵdé podporované území u smluvního partnera vytvoŚen realizal ní tým. Ten je zodpovhlný plnßní úkolT uvedených v projektové ǵádosti.

Realizal ní tým se skládá z následujících osob:

a) Koordinátor meziobecní spolupráce

Náplní práce zamßștnance smluvního partnera je:

- komunikace se zástupci dot!l ených obcí a partnery v území správního obvodu obce s rozğŚśnou p丁sobností,

- objasŔování cílT meziobecní spolupráce ve správním obvodu obce s rozğŚśnou pTsobností,

- zdTrazŔování pŚnosT pro participující obce,

- identifikace dalğch klí| ových aktérT (tj. moğných budoucích partnerT v území správního obvodu obce s rozġśśnou p丁sobností), podpora porozumßní a sounáleǵitosti,

- vytváŚní vazeb mezi obcemi, pŚspívání k Śggení konkrétních problémT,

- moderování veŚjjých debat a jednání,

- napomáhání vzájemnému konsensu,

- pomáhání v identifikaci spolel ných zájmT,

- hledaní vhodných Śġení, pomáhání pŚ formulaci závク̣T,

- nastavování vazeb mezi obcemi a koordinuje pŚpadný proces institucionalizace meziobecní spolupráce ve variant Đzvolené pŚdstaviteli obcí z daného území,

- komplexní Śzení projektu na úrovni Smluvního partnera (plnḩí úkolT, soulad s harmonogramem a reporting výstupT smf̧em ke Svazu),

- Śzzení !̣innosti dalğch !̣lenT Realizal ního týmu (rozdhování úkolT, kontrola výstupy, atd.), zamßşnanec také plní dalğ úkoly spojené s realizací Projektu.

b) Pracovník pro analýzy a strategie

Náplní práce zamß̧tnance smluvního partnera je:

- analyzování a definování v'cného potenciálu meziobecní spolupráce v pŚslug̉ném správním obvodu obce s rozǵśśnou p Tsobností,

- nastavování priorit vzájemné spolupráce,

- pŚprava veg̉kerých analytických podkladT a syntézy pro setkání zástupcTobcí,

- zpracovávání situal ních analýz rozvojových strategií a hodnocení dostupnosti vybraných veŚjeých sluǵeb v území,

- tvoŚ návrhy, strategie a koncepce pro Územní obvod,

- zamßstnanec téǵplní dalğ úkoly spojené s realizací Projektu.

c) Asistent

Zamß̧tnanec p丁sobí jako asistent koordinátora meziobecní spolupráce, pracovníka pro analýzy a strategie a odborníka na vybranou samosprávnou oblast, pŚ| emǵ náplní práce zamß̧̧tnance je:

- zajiớsování technické podpory !̣innosti Realizal ního týmu,

- vedení projektové dokumentace,

- podílení se na zpracování zpráv o linnosti a na díl! ích výstupech,

- organizal ní zajiơšování setkání pŚ́dstavitelT obcí,

- organizal ní zajioğování jednání s dalğmi partnery,

- dalğ administrativní ! innosti spojené s fungováním Realizal ního týmu,

- zamß̧tnanec také plní dalğ úkoly spojené s realizací Projektu.

d) Odborník na vybranou samosprávnou oblast (tematický expert)

Zamß̧tnanec vykonává práci spojenou s konkrétním zvoleným Volitelným tématem, pśḷ emǵ konkrétní náplní práce zamß̧tnance je:

- definování v f̧ného potenciálu meziobecní spolupráce, 
- rozpracování a navrğení vhodných Śġení, stejnĐjako vytvoŚní strategie a koncepce pro Územní obvod, které budou moci být v alternativách pŚedloǵeny pŚédstavitelTm obcí v Územním obvodu, zamh ḩtnanec také plní dalğ úkoly spojené s realizací Projektu,

- výǵe úvazku je odvyslá od poḷ tu obcí tvoŚcích dané území ORP.

V projektu jsou zpracovávána dTheǵitá témata spojená se samostatnou pTsobností obcí, vyplývající ze zákona o obcích - jako je pŚedġkolní a základní ğkolství, sociální sluğby a nakládání s odpady (tzv. základní témata) a jedno pŚpadnクdvクvolitelná témata, které odráǵi individuální rozvojové potŚbby $\mathrm{m}$ ḩt a obcí v území ORP. V tḩh územích, kde je $\mathrm{m}$ 乃̧to s více neǵ 25 tis. obyvateli, se jako jedno $\mathrm{z}$ moǵných volitelných témat doporul uje meziobecní spolupráce $\mathrm{v}$ aglomeraci. ZároveŔ vğechny uvedené oblasti obsahují prTŚ́zové téma, kterým je zefektivnhní výkonu veŚjné správy (mj. i s dTrazem na úspory a finan! ní výhodnost vzájemné spolupráce).

PŚ tvorbク analýz a rozvojových strategií je poskytována ze strany Svazu metodická podpora prostŚdnictvím vytvoŚného týmu odborník丁ï analytik丁 a metodikT, kteŚ se specializují na základní témata, pŚpadnク na procesy meziobecní spolupráce. ProstŚdnictvím projektuje obcím, mßstJm a dobrovolným svazkTm poskytována podpora v oblasti právního rámce spolupráce, úpravy, zakládání ! i transformace svazkT.

\section{Stávající výsledky projektu}

Smlouva mezi poskytovatelem Ministerstvem práce a sociálních v hí L LR jako poskytovatele dotace a Svazem $m$ ḩ̣t a obcí L̦R jako pŚjemcem byla uzavŚna dne 9. záŚ 2013. V prTbhu léta a podzimu dog̉o k vytvoŚení vedoucího realizal ního týmu, který zajiğšje jak technickou realizaci projektu, tak i prostŚdnictvím tzv. regionálních koordinátorT vazbu na územní týmy zamß̧̧tnávané smluvními partnery. Celkem bylo vytvoŚneno 14 pozic koordinátorT, z nichǵ kaǵdý dostal do vínku cca 16 území ORP. Regionální koordinátoŚ identifikovali v kaǵdém území ORP smluvní partnery Svazu (vǵdy pouze jednoho pro kaǵdé území), kteŚ by se stali nositeli projektu v území. Podmínkou jejich zapojení byla jak identifikace s cíli projektu tak i schopnost vést komunikaci s obcemi tvoŚcími území daného ORP. Následnクse zapojili do debaty o meziobecní spolupráci a monitoringu tvorby analýz a návrhT rozvoje meziobecní spolupráce.

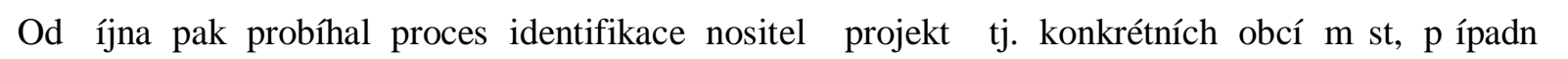
dobrovolných svazkT obcí (DSO). Podmínkou zpTsobilosti byl veŚsjnoprávní charakter nositele projektu v území tj. smluvního partnera. Jiné formy spolupráce vytváśéné podle ob!̣anského !̣i obchodního zákoníku nebyly z povahy projektu pŚpustné. Nejvhğ poḷ et smluv mezi Svazem a nositeli projektu byl uzavŚen v období listopad 2013 aǵ leden 2014. V pŚpadク území ORP v Moravskoslezském kraji byly díky brzké ! innosti tzv. pilotní regionální koordinátorky, která zal ala v území p丁sobit jiǵ od !̣ ervence 2014, smlouvy uzavírány Śjnu a listopadu. Rychlé navázání smluvních vztahT probíhalo rovnhǵ v kraji Jihomoravském a PlzeŔském. Vクğna regionálních koordinátorT zapol ala svou !̣innost cca od srpna a záŚ 2013 a tomu odpovídají i pozdnğ termíny uzavírání smluv.

Tab. 1: Zastoupení smluvních partnerT

\begin{tabular}{|l|c|c|c|c|}
\hline Stav k: & Obec & Obec & Obec ORP & DSO \\
\hline 31.Śjnu 2013 & 8 & 4 & 4 & 11 \\
\hline 30.listopadu 2013 & 46 & 17 & 29 & 41 \\
\hline 31.prosinci 2013 & 26 & 10 & 16 & 15 \\
\hline 31.lednu 2013 & 16 & 6 & 10 & 14 \\
\hline 28.únoru 2013 & 1 & 0 & 1 & 3 \\
\hline 31.bŚeznu 2013 & 2 & 1 & 1 & 2 \\
\hline Celkem & 99 & 38 & 61 & 86 \\
\hline
\end{tabular}

Zdroj: SMO L̦R, Projektová kanceláŚ odborný tým 
PŚ identifikaci partnerT v území regionální koordinátoŚ uskutel nili celou Śd schTzek, jak s mß̧tem ORP, tak s místními DSO i dalğmi mßşty a obcemi v konkrétním území ORP. PŚ uzavírání smluv se

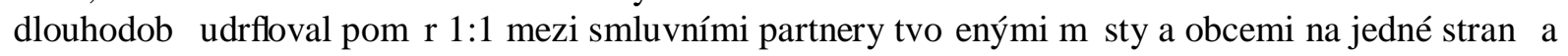
DSO na stranクdruhé. Stav k 31. bŚźznu byl lehce vychýlen ve prosphth mht a obcí $54 \%$ ku $46 \%$ DSO. Podíl obcí s rozǵŚ́nou pJsobností jako smluvního partnera Projektu ḷiní $33 \%$.

\section{Kartogram 1: Stav uzavŚných smluv}

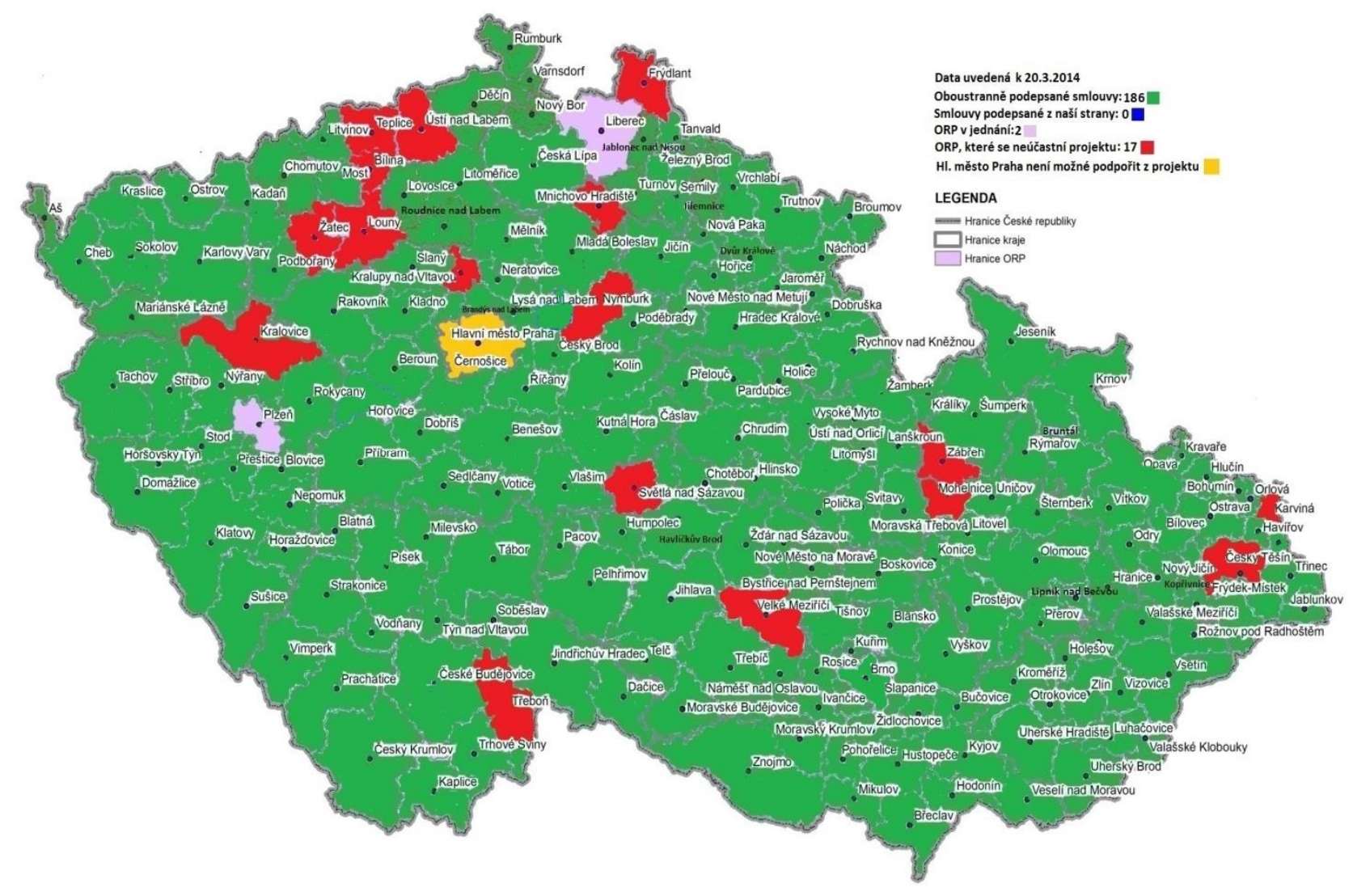

Zdroj: SMO L R, Projektová kanceláŚ odborný tým

\section{První zjiộ̣í ul inhá prostSednictvím projektu}

V prTb円uu prosince aǵ února, pŚd vlastním spug̉ní analytických prací a debat o meziobecní spolupráci), probநhlo vúzemí základní zjiğhní postoj丁 obcí a $\mathrm{m}$ ḩt k meziobecní spolupráci, prostŚdnictvím Śzeného rozhovoru (výjimel nクformou dotazníku, tzv. Dotazník 1). Smyslem této aktivity zajiğŠované realizal ními týmy Smluvních partnerJ bylo rovnhǵ zajistit informovanost vğech obcí v území daného ORP o cílech a zámクţech Projektu, pŚsvnłl ovat starosty obcí k jejich aktivnímu zapojení do Projektu. Z monitorovacích zpráv z území k 28. 2. vcelku jednoznal nךvyplývá vysoký zájem oslovených obcí (jejich p\$́dstavitelT) zapojit se Projektu ï avízovaný zájem kolísá mezi 60 ï

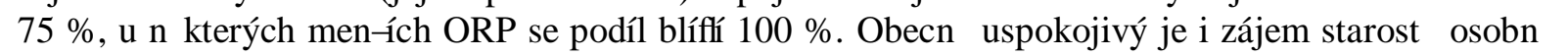
se podílet na prohlubování meziobecní spolupráce na území daného ORP - zde je patrná vyğğ aktivita

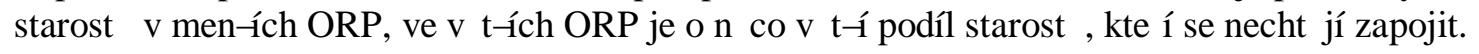

Z monitoringu neformálních setkávání starostT v území ORP dále plyne, ǵe ve vğech územích ORP probநhlo jiğ nholik thchto setkání, kde byly g̈roce diskutovány pŚedstavy jednotlivých starost丁 o významu a moǵnostech meziobecní spolupráce a jejich vlastního zapojení do Projektu.

Dotazník 1 byl koncipován jako Ăuvozující podkladový materiálñ pro vstupní analýzu stávající MOS v jednotlivých území ORP. Ġo o to, aby se koordinátor MOS seznámil s názory starost T na problematiku meziobecní spolupráce v podmínkách daného území ORP a zároveŔ objasnil smysl a 
cíle naġeho projektu. Proto se v metodickém pokynu kladl velký dTraz na vyuğití formy Ắ́zeného rozhovoruñ koordinátora MOS se starosty. Z monitoringu vyplývá vysoká oslovenost obcí formou Śzeného rozhovoru - u menǵ̛ch a stŚedn门 velkých ORP podíl kolísá kolem 85-100 \%, pouze u nhterých velkých ORP (pol et nad 80 obcí) je tento podíl niğǵ. Celkov门se zapojilo více neǵ 5000 obcí.

Smyslem vstupního getŚení bylo Ăzmapováníñ stávajících zkuġeností a názorT starostT na problematiku spolupráce obcí v rTzných oblastech samostatné p丁sobnosti obcí. GetŚení se soust Śdilo na zjiğhí spokojenosti se spoluprací sousedících obcí. Graf 1: Odpov Yyi na otázku: Jak hodnotíte spolupráci mezi sousedními obcemi (tedy s thni, se
kterými sousedí vág katastrální území)?

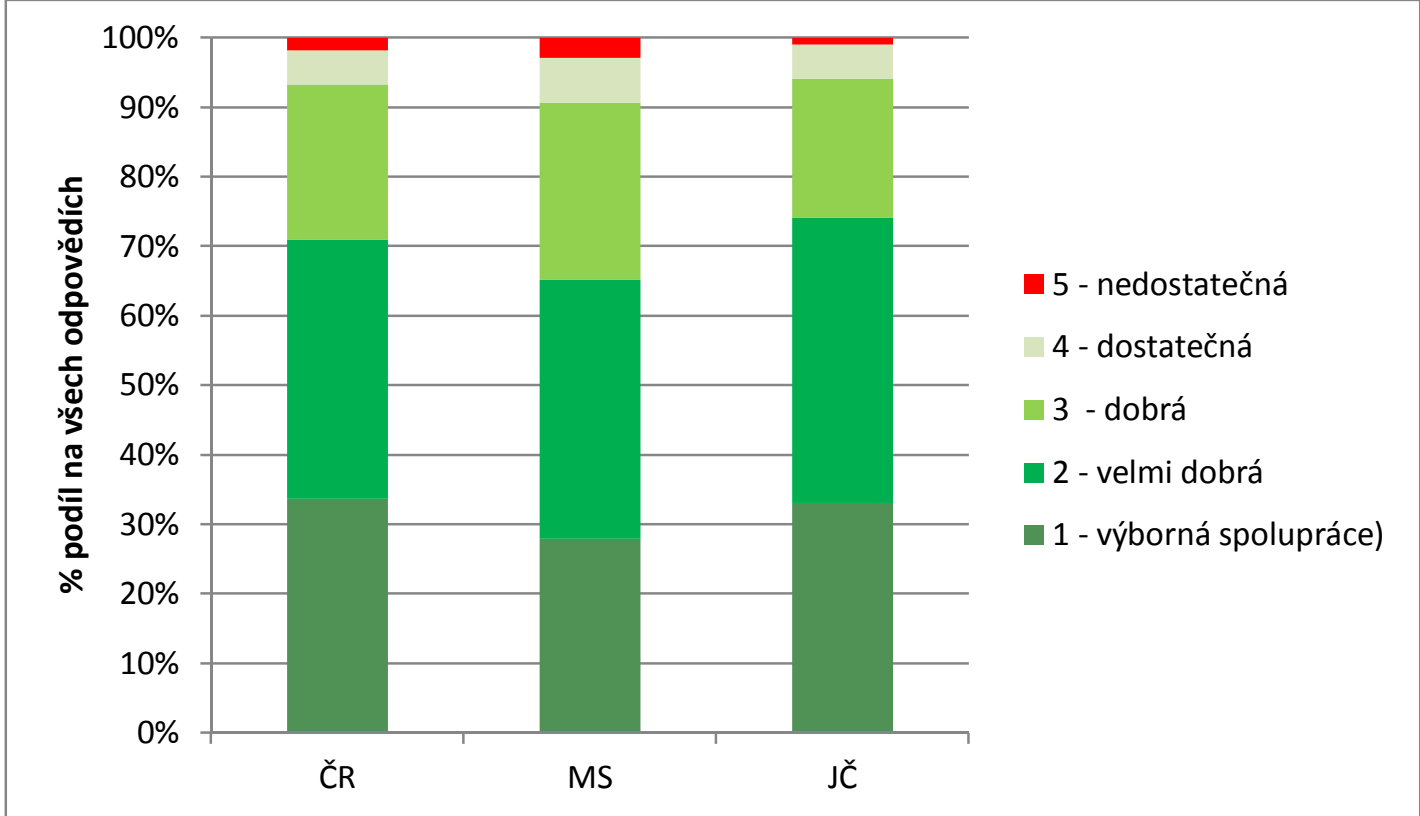

Zdroj: SMO L̦R, Projektová kanceláŚ odborný tým, výsledky terénního ğ̉tśení

Pro napln hyí cílT projektu je nezbytné dobŚ posoudit ochotu ḷ i naopak pŚpadnou averzi ḷ i nechuŠk vzájemné spolupráci sousedících obcí. Z grafu !. 1 charakterizuje spokojenost obcí se spoluprací. $\mathrm{K}$ údaj $\mathrm{Tm}$ za celou $L \mathrm{R}$ je jako kontrast zaŚzeno území Jihol eského kraje $̈ ̈ \mathrm{JL}$, venkovské ORP s vhğm poḷ tem obcí, a Moravskoslezského kraje ï MS, pŚeváǵnך urbanizované území, tvoŚené územnクmalými ORP s malým poḷ tem obcí.

Situace v celé L̦R je velmi pozitivní. Jako výbornou vzájemnou spolupráci hodnotí cca $33 \%$ vg̉ech

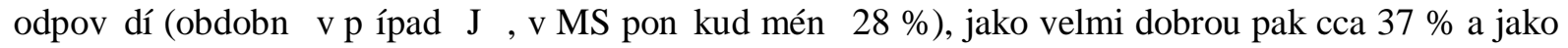
dobrou cca $22 \%$. Z pohledu celé L LR obce hodnotí ÁroveR sousedských vztahTĂ jako dobrou aǵ výbornou v cca $93 \%$ odpov hí. Rozdíly mezi L R a obクna kraji nebyly podstatné. Vysoký podíl pozitivních odpovĐí pŚedstavují dobré východisko pro nastartování procesu formování tzv. komunika! ní platformy pro proces prohlubování meziobecní spolupráce, tedy pro neformální setkávání starost T v území ORP organizovaných koordinátory meziobecní spolupráce a motivujícími starosty. Stav v urbanizovaném a venkovském regionu nevykazuje výraznクğ rozdíly.

Jednou ze zkoumaných oblastí byla spokojenost obcí se spoluprací s okolními obcemi dle vybraných oblastí samostatné pTsobnosti obcí. Velmi vysoké preference jsou u oblasti ġolství (cca $65 \%$ obcí) a dobrovolných hasil T (spojeno i s problematikou pomoci pŚ krizových situacích), vysoké jsou i preference oblasti kultury, sportu a spolkové ! innosti ï zde respondenti z Jihol eského kraje vykazují mírnநvyg̣g preferenci neǵ Moravskoslezký kraj i celá L̦R. Z pohledu projektu jsou nadநné preference

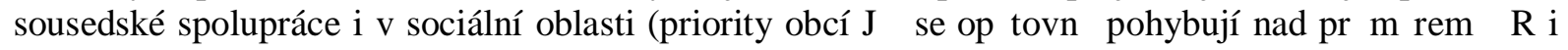


MS) i v odpadovém hospodáŚství. Rozdíly vğkk nejsou zásadní. Lze pŚdpokládat budoucí ochotu obcí spolupracovat v tḩhto oblastech i v úrovni celého území ORP.

Graf 2: Odpov1li na otázku: OhodnoŠte oblasti dle vag்ho názoru naprosto vhodné a velmi vhodné pro meziobecní spolupráci

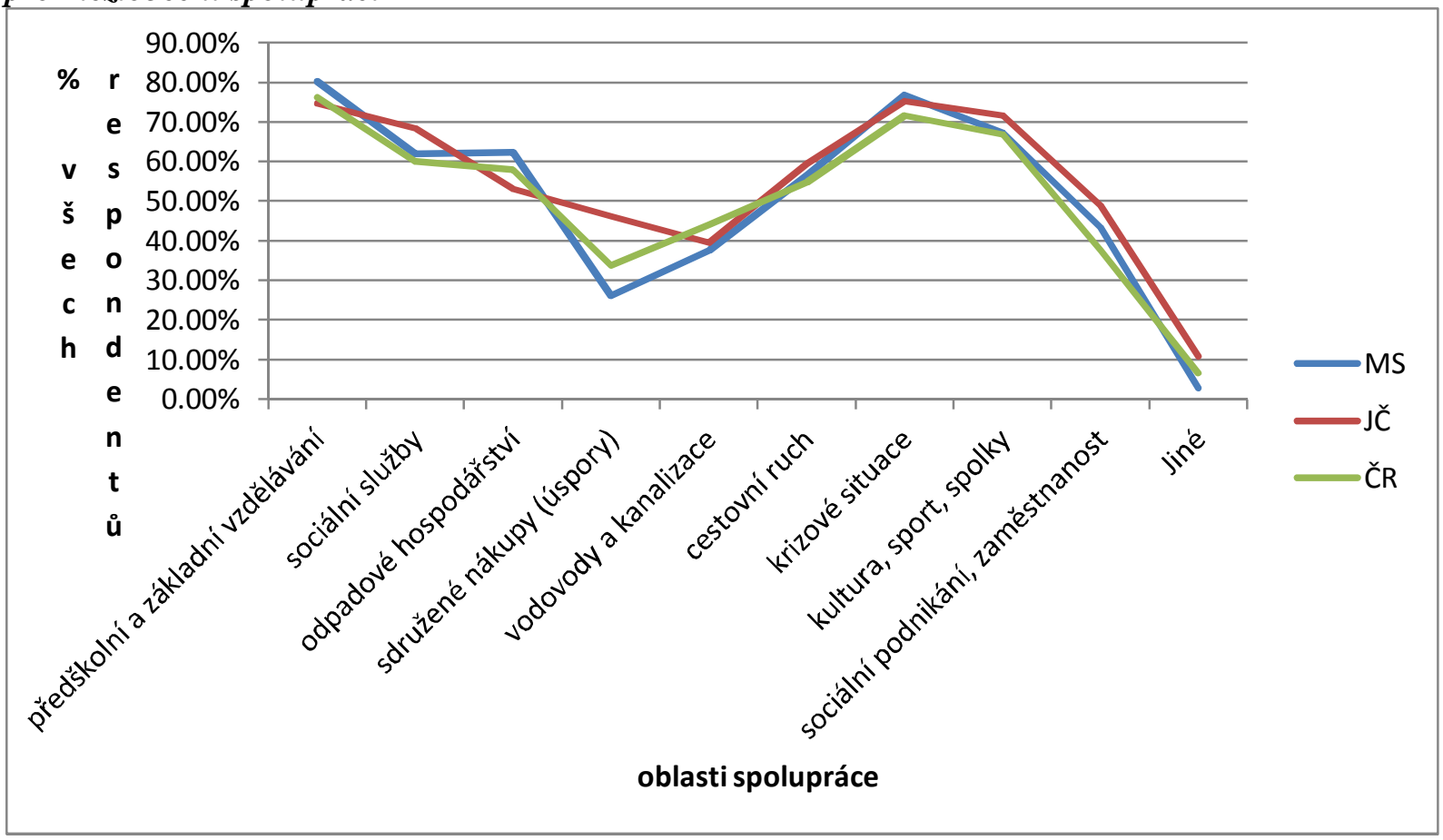

Zdroj: SMO L̦R, Projektová kanceláŚ odborný tým, výsledky terénního ġetŚní

Starostové v ġetŚní rovnhğ pŚdstavili své zkug̉enosti a svoje názory na nhteré bariéry (pŚekáǵky a obtíǵe) pŚ praktické realizaci meziobecní spolupráce. Jako významnou aǵ velmi významnou bariéru vidí starostové nedostatek financí a v nedostatel nou ḷi sloğitou legislativu, v meng̛ míś pak v nízké podpoŚ ze strany státu.

\section{Graf 3: Odpov'li na otázku: Jaké vidíte nejv'gg̉ bariéry meziobecní spolupráce?}

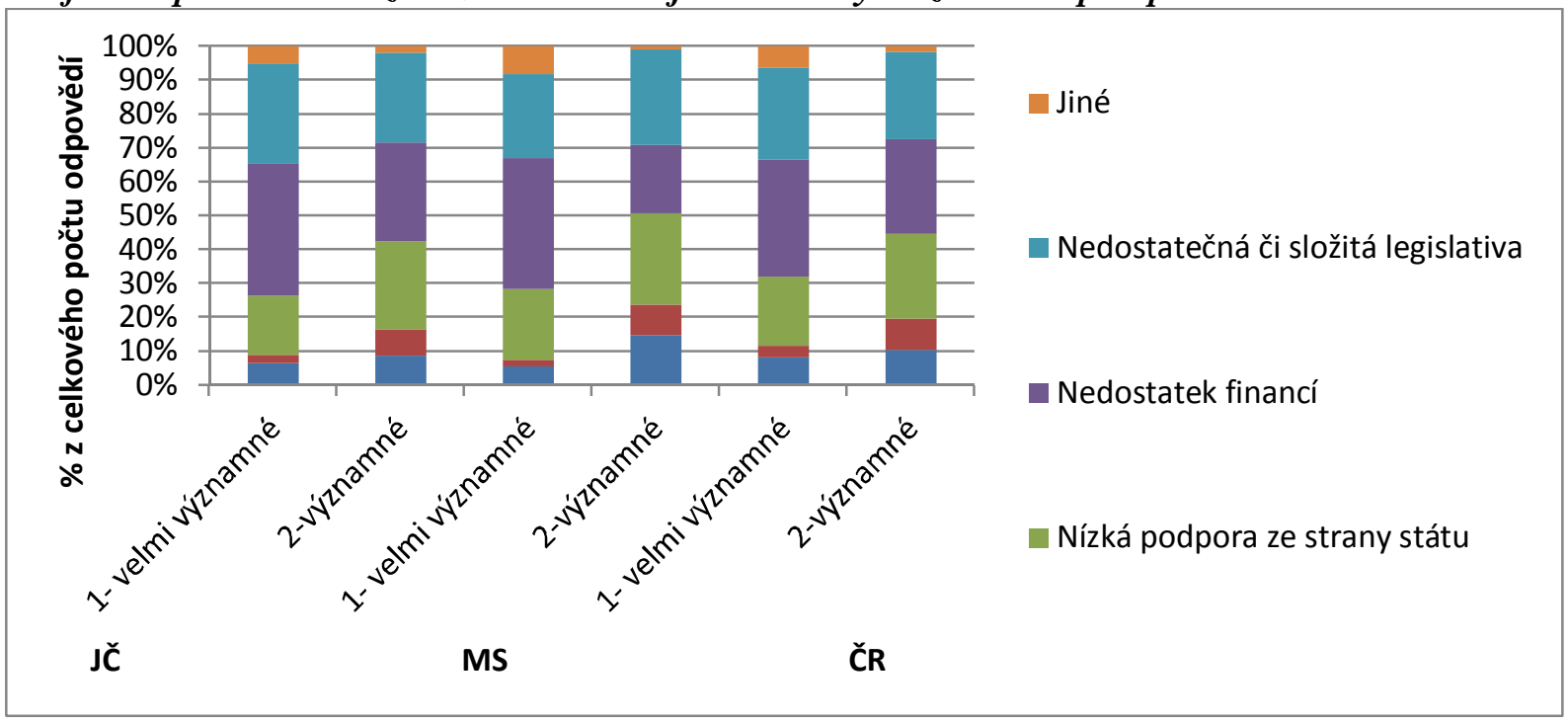

Zdroj: SMO L̦R, Projektová kanceláŚ odborný tým, výsledky terénního ġetŚéní

Ǵpatné fungování, Śzení li právní formu spolupráce vidí starostové jako velmi významnou (!̣i významnou) bariéru pouze v $10 \%$ odpov hlí a neochotu, nezájem li neplnhí dohod vidí jako významnou bariéru cca 8- $10 \%$ odpovflí, pouze v MS kraji je mírnク vyğg் (cca $14 \%$ ). V 


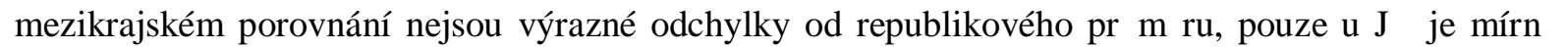
vyğğ podíl u nedostatku financí pŚ menğm podílu nízké podpory ze strany státu.

Co se tý! e formy meziobecní spolupráce, tak vedle klasické neformální spolupráce mezi obcemi a stávajícího svazku obcí, starostové jako dalg̀ v poŚidí s preferencí nejvhodnクğ formy spolupráce, oznal ili Shromáǵdhní pŚedstavitelT obcí, které je podporováno i v rámci Projektu.

PŚ zjiğŠování názoru starost J byla poloǵena i otázka ohlednク pŚnosnosti institutu okresního

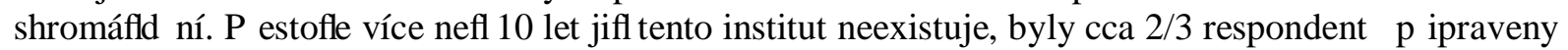
se k tomuto institutu vyjádŚt a povaǵovaly ho za pŚnosný.

\section{Graf 4: Odpov'li na otázku: Jaký máte názor na institut okresního shromáǵłhií}

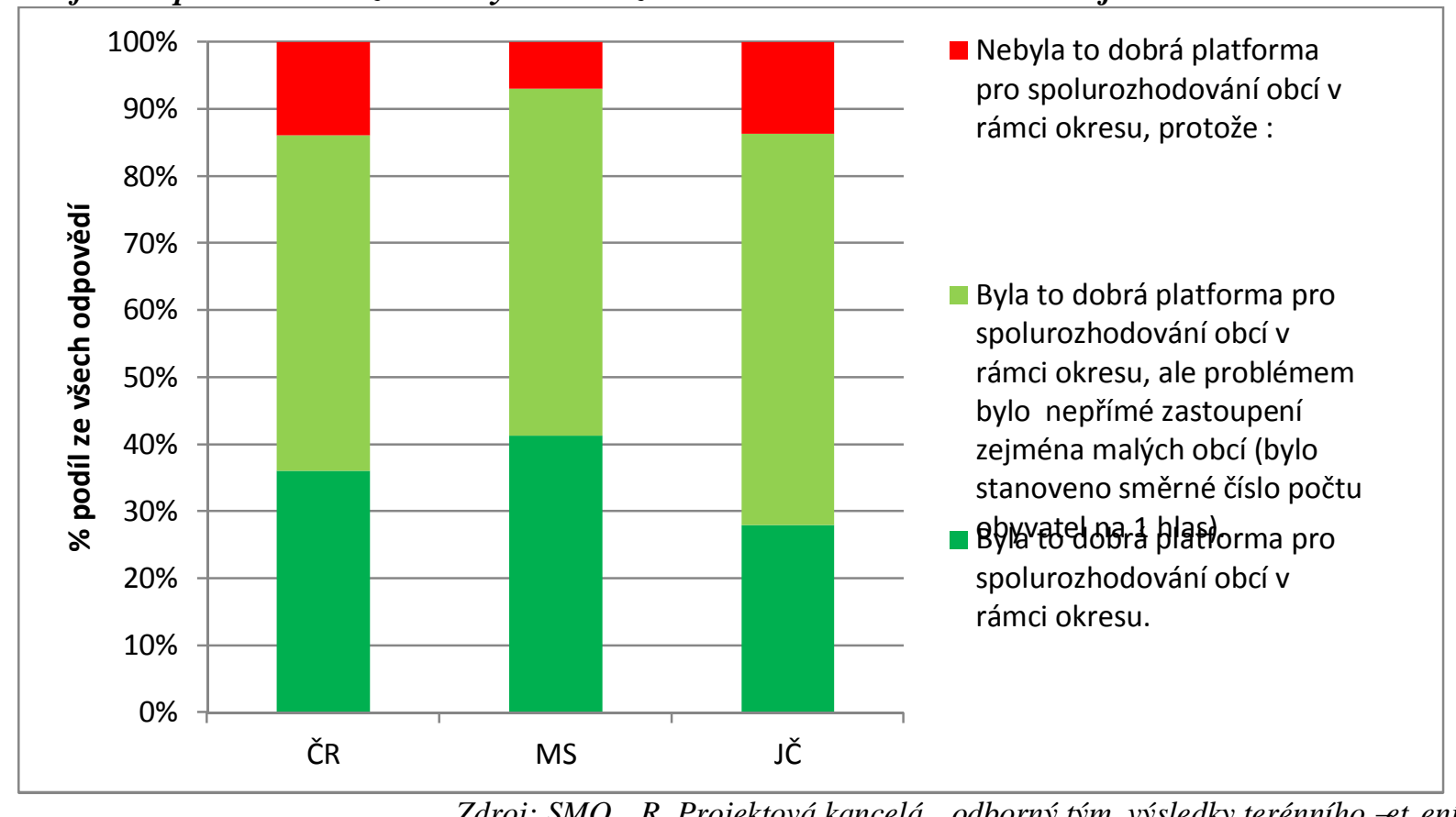

Toto zjiğ円uí, ve spojitosti s vysokým podílem pozitivního ocen円uí institutu okresního shromáǵdhií

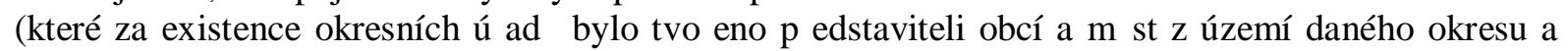
bylo platformou k prosazování spolel ného zájmu obcí ve vztahu k okresnímu úŚdu, potaǵmo státu), vytváŚ dobré výchozí podmínky pro moderování celého procesu prohlubování meziobecní spolupráce v zajiớšvání dostupnosti vybraných veŚjných sluǵeb v rámci Projektu.

\section{Závhy}

V LR se rovnhğ́prostŚednictvím projektu ĂSystémová podpora rozvoje meziobecní spolupráce v LR v

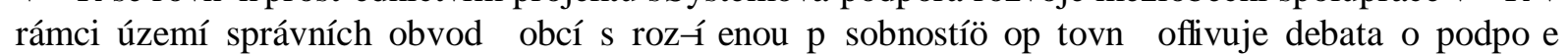
meziobecní spolupráce, jejích pŚnosech pro zajiğhií dostupnosti veŚjjých sluǵeb zajiğŠovaných $\mathrm{m}$ hty a obcemi v samostatné pTsobnosti. Zdá se, ǵe podmínky pro její rozvinutí jsou pŚznivé. Obce a $\mathrm{m}$ ß̧ta mají pozitivní zkuġenosti se stávající meziobecní spoluprací. Z jejich strany je doceŔován význam meziobecní spolupráce jako mechanismu umoğŔujícího prosazování svých zájm丁 i pro efektivnクğ zajiğnií veŚsjných statkT a sluǵeb, za jejichǵ dostupnost nesou zodpovhlnost. Tento postoj je zásadní vzhledem $\mathrm{k}$ zájmu nové vlády pŚstoupit $\mathrm{k}$ dokonl ení druhé fáze reformy veŚjné správy. Je zde obrovská pŚleğ́tost prosadit systémovou podporu meziobecní spolupráce jako vládní politiky, podobn Đjako je tomu v jiných zemí s obdobnou sídelní strukturou (typicky Francie), uzavŚt debaty o moǵném administrativním sniǵování poḷ tu obcí. Dosavadní zjiğnî́, vyplývající z pŚedb hóných ğetŚní, naznal ují pŚpravenost komunální scény tuto otázku otevŚt. 
Svaz $\mathrm{m} h$ t a obcí LLR prostŚednictvím projektu Systémová podpora rozvoje meziobecní spolupráce v L R $\mathrm{v}$ rámci území správních obvodT obcí s rozǵś́nou pTsobností (líslo projektu: CZ.1.04/4.1.00/B8.00001), podpoŚeného z prostŚedkT ESF a státního rozpoḷ tu prostŚednictvím OP LZZ, usiluje o zahájení diskuse o moǵnosti meziobecní spolupráce na bázi samostatné pJsobnosti v území ORP. Bude podporovat i vyugóití poznatkT a pŚkladT dobré praxe ze zahranil ní v l eském kontextu. Stimulace meziobecní spolupráce mTgáe vést ke vzniku nové formy DSO, který by pTsobil území ORP vytvoŚl by tak pevný základ k hájení zájm丁 mḩt a obcí pŚ jednáních se státem krajem, dalğmi partnery v území. Dalğ úlohou by bylo zajiğSování nabídky konkrétních veŚjjých sluǵeb dle preferencí území.

\section{Literatura}

[1] BLAG̣EK, J., (2002). System of Czech local government financing as a framework for local development: 12 years of trial and error approach. Acta Universitatis Carolinae ï Geographica, vol. 37, iss. 2, pp. 157173. ISSN 0300-5402.

[2] HAMPL, M., DOSTÁL, P., (2007). Geography and territorial administration in the Czech Republic: Issues of fragmentation and rescaling. Acta Universitatis Carolinae - Geographica, vol. 42, iss. 1-2. ISSN 23361980 .

[3] HAMPL, M., MÜLLER, J., (1998). Jsou obce v Leské republice pŚlig̉malé? Geografie ï Sborník ! eské geografické spole! nosti, vol. 103, iss.1, pp. 1-12. ISSN 1212-0014.

[4] JETMAR, M., HUGGERA,J., (2013). Význam a postavení územního obvodu ORP ve struktuŚs regionálního rozvoje, Svazek obcí územního obvodu ORP. Regionální rozvoj mezi teorií a praxí, iss. 2, pp. 12. Civitas per Populi a Vysoká ǵkola regionálního rozvoje Praha. ISSN 1805-3246.

[5] JETMAR, M., (2013a). The importance of the territorial district of municipality with extended power (ORP) for regional development and its possible use in solving common tasks within the original competence of municipalities. In 16th International Colloquium on Regional Sciences. Conference Proceedings. Brno: Masarykova univerzita. pp. 358-365. ISBN 978-80-210-6257-3. DOI 10.5817/CZ.MUNI.P210-6257-2013-44.

[6] JETMAR, M., (2013b). Nová forma meziobecní spolupráce v územním obvodu ORP a její moǵnosti vyugóití pro spoleḷ né Śgéní úkolT v samostatné pJsobnosti obcí. In Region v rozvoji spole! nosti 2013. Brno: Mendelova univerzita v BrnП ISBN 978-80-86131-82-5.

L̦lánek byl vytvoŚ $v$ souvislosti s realizaci projektu Systémová podpora rozvoje meziobecní spolupráce $v \mathbf{L} \boldsymbol{R}$ v rámci územi správních obvodT obcí s rozg்Śnou pTुsobnosti (】íslo projektu: CZ.1.04/4.1.00/B8.00001), podpoŚného z prostŚdkT ESF a státního rozpoḷtu prost Śdnictvím OP LZZ. 